\title{
PENGARUH LATIHAN FOOTWORK BERBASIS TEKNOLOGI TERHADAP KELINCAHAN DAN DAYA TAHAN SEKOLAH ATLET PB. LYANSA 2019
}

\author{
Lalu Sapta Wijaya Kusuma ${ }^{1}$, Aminullah $^{2}$ \\ IKIP Mataram \\ lalukusuma2@gmail.com
}

\begin{abstract}
Abstrak . Salah satu bentuk latihan yang paling sering diterapkan dalam latihan bulutangkis adalah shadow movement (latihan bayangan), latihan ini bertujuan untuk mensimulasikan permainan bulutangkis untuk melakukan olah kaki (footwork) secara baik dan benar. Namun bentuk latihan tersebut terbilang sudah cukup klasik di dunia bulutangkis sehingga perlu adanya formula dan media khusus yang dapat memberikan motivasi dan semangat baru ketika atlet berlatih. Sehingga dalam hal ini peneliti mencoba menerapkan latihan berbasis teknologi sebagai pengganti shadow movement. Tujuan yang ingin dicapai dalam penelitian ini adalah untuk mengetahui efektif atau tidak latihan footwork berbasis teknologi dalam mengingkatkan kelincahan dan daya tahan atlet bulutangkis. Jenis penelitian ini adalah eksperimen dengan menerapkan pretest dan posttest pada subjek yang diteliti berupa tes awal sebelum dan tes akhir berupa tes kelincahan dan daya tahan. Intrumen kelincahan dilakukan Tes rangkaian olah kaki untuk mengukur kelincahan gerakan kaki yang melangkah ke depan kanan-kiri, ke samping kanan-kiri, dan belakang kanan-kiri dalam permainan bulutangkis. Tes ini dikemukakan oleh Tohar (1992). Tes ini mempunyai validitas sebesar 0,98 dan reliabilitas sebesar 0,93. Sedangkan untuk mengukur daya tahan digunakan bleep test. Populasi dalam penelitian ini sebanyak 12 pemain bulutangkis PB. Lyansa. Tehnik pengumpulan data dalam penelitian ini menggunakan dokumentasi dan tes perbuatan untuk mengukur kelincahan dan daya tahan. uji-t paired sample test. Adapun hasil penelitian berkesimulan dengan bantuan SPSS adalah korelasi maupun uji paired samples T-test hasil kelincahan ( $\mathrm{r}$-hitung $=0,801$ dan T-test $=8,095$ ) lebih kecil pengaruhnya dibandingkan dengan daya tahan $(\mathrm{r}=0,959$ dan $\mathrm{T}=9,706)$, atau dengan kata lain latihan footwork berbasis teknologi lebih berpengaruh terhadap daya tahan dari pada kelincahan. Dengan demikian dapat disimpulkan bahwa latihan footwork berbasisi teknologi dapat meningkatkan kelincahan dan daya tahan pemain bulutangkis khususnya atlet PB. Lyansa Masbagik tahun 2019.
\end{abstract}

Keyword: footwork berbasisi teknologi, kelincahan dan daya tahan dalam permainan bulutangkis.

\section{PENDAHULUAN}

Untuk meningkatkan footwork dengan tehnik konvensional biasanya dilakukan dengan cara menempatkan bola (shuttlecock) diberbagai sudut lapangan permainan, dan pemain ditugaskan menjangkau bola tersebut dan menempatkan kembali bola/cock tersebut ke sudut yang lain,. Dan atau dengan maju mundur dari belakas garis belakang dan maju sampai ke dekat net seolah-olah pemain bersiap mengambil bola netting, dan seterusnya. Yang dalam hal ini peneliti menyebutnya sebagai sistem pelatihan footwork konvensional. Namun berbeda dengan footwork dengan berbasis teknologi nearkabel yang merupakan pengembangan dari footwork manual. Alat tersebut dibuat tanpa kabel dan ditempatkan diberbagai sudut lapangan dengan sinyal cahaya sebagai penanda arah gerakan yang harus dilakukan oleh pemain. Footwork merupakan tehnik yang paling mendasar dan utama yang harus dimiliki oleh seorang atlet bulutangkis, baik dan tidaknya suatu footwork ditentukan oleh system pelatihan yang tepat dalam pengembangannya. Menurut Krisdiyana, (2010) sistem pelatihan dengan bola lampu dapat merangsang gerak reaksi olahragawan bulutangkis. Artikel, posted on Desember 15. 2010 .

Dari hasil wawancara peneliti dengan pelatih PB. Lyansa merespon sangat positif dan menyambut baik jika kegiatan tersebut memang benar terlaksana (Aziat pelatih PB. 
Lysansa). Menurut pelatih PB. Lyansa terciptanya alat tersebut dapat mengembangkan keterampilan footwork para pemain dengan sistem yang lebih modern, hal tersebut akan menambah motivasi para pemain dalam berlatih, sehingga secara tidak langsung akan meningkatkan prestasi pemain yang ada di PB. Lyansa Masbagik utara.

Pemilihan footwork berbasis teknologi ini dipilih berdasarkan observasi yang diakukan oleh peneliti di club-club Pembina olahraga prestasi bulutangkis, khususnya yang ada di masbagik masih menggunakan system pelatihan footwork manual dari dulu hingga sekarang dengan model yang sama yaitu menempatkan bola diberbagai sudut lapangan permainan yang harus dijangkau oleh pemain dan ditempatkan ke sudut yang lain, dan atau dengan model shadow movement. Sehingga model pelatihan tersebut cukup membuat para pemain cepat bosan karena dilakukan kurang lebih 6 bulan dan bahkan lebih untuk membentuk dasar footwork yang baik, namun tergantung dari tingkat penguasaan gerak dari para pemain yang berlatih.

\section{Latihan Footwork Berbasis Teknologi}

Hal yang paling mendasari dari penelitian ini adalah semua tehnik pelatihan yang digunakan untuk melatih footwork adalah dengan menempatkan bola di berbagai sudut lapangan, namun dalam hal ini footwork dengan menggunakan teknologi ditempatkan didepan dekat net, ketika alat tersebut menyala atlet akan bergerak sesuai posisi dari alat tersebut. Setiap atlet melakukan gerakan ke depan, samping, maupun ke belakang harus diakhiri dengan kebali ke tengah lapangan, seterusnya. Sehingga dari sinyal tersebut atlet seolah-olah sedang melakukan pertandingan ada lawan main dengan adanya alat tersebut. Pengembangan alat latihan footwork yang sifatnya manual ke Footwork yang menggunakan teknologi berbasisi remote kontrol diharapkan dapat meningkatkan kelincahan dan daya tahan pemain bulutangkis yang ada PB. Lyansa Masbagik utara. Menurut Purnama (2010) prinsip dasar footwork dalam permainan bulutangkis adalah kaki yang sesuai dengan tangan yang digunakan untuk memegang raket saat memukul selalu berakhir sesuai arah tangan tersebut. Menurut Krisdiyana (2010) terdapat 6 wilayah yang dapat meningkatkan kecepatan dengan menggunakan media alat, antara lain; 1) Melatih kecepatan reaksi dengan sinyal atau stimulus dari luar, 2) Mempercepat kapasitas gerak, 3) Kapasitas untuk mengatur keseimbangan kecepatan, 4) Meningkatkan prestasi dari kecepatan maksimum, 5) Kapasitas mempertahankan kecepatan maksimum, dan 6) Kapasitas akhir dari pengaruh faktor daya tahan pada kecepatan.

Adapun bentuk alat yang dimaksudkan, baik letak, dan kegunaannya dalam meningkatkan footwork pemain dapat dilihat pada gambar 2.1 dibawah ini.

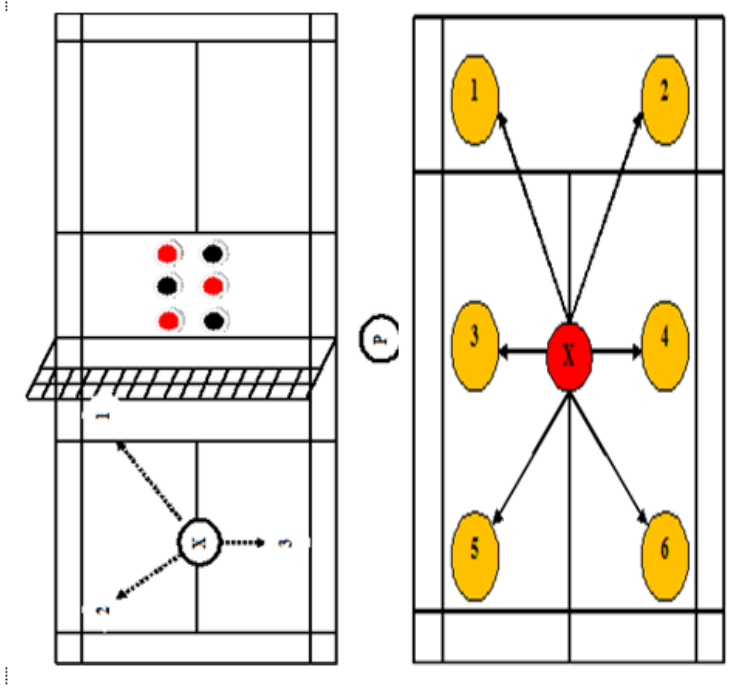

Gambar 1 \& 2 diolah oleh Peneliti (2019).

Keterangan:

$\mathrm{X} \quad$ : testee (pemain) yang melakukan gerakan footwork

P : peneliti yang menekan alat sinyal gerak

(1) : alat footwork yang menyala (arah sinyal gerak testee).

$\rightarrow 132:$ arah gerakan testee (pemain)

Gambar penempatan lampu isyarat sebagai simulasi arah gerakan bisa diliha pada gambar dibawah ini:

\section{Pelaksanaan:}

1. Pemain berdiri di tengah lapangan dengan sikap siap melakukan gerakan

2. Pemain melakukan gerakan ketika lampu sinyal dan sekaligus menandai arah gerakan yang harus dilakukan oleh testee

3. Setiap pemain melakukan satu kali gerakan harus kembali ke tengah lapangan permainan (tanda ' $\mathrm{X}$ ' pada lapangan) 
4. Lampu 1 menyala testee harus bergerak ke depan sudut kiri permainan (pukulan netting ataupun return)

5. Lampu 2 menyala pemain bergerak ke belakang sudut kiri permainan

6. Lampu 3 menyala testee bergerak ke samping kanan permainan, dan

7. Seterusnya berlanjut sampai ke 6 (enam) atau semua lampu menyala menandai berakhirnya gerakan.

\section{Kelincahan Dan Daya Tahan Dalam} Olahraga Bulutangkis

Keterampilan bermain bulutangkis adalah penguasaan gerak mulai dari keterampilan dasar sampai dengan tingkat yang lebih tinggi seperti:, lob, dropshoot, dan smash.

\section{Footwork (olah kaki) Bulutangkis}

Dalam permainan bulutangkis, kaki berfungsi sebagai penompang tubuh untuk bergerak ke segala arah dengan cepat, sehingga dapat memposisikan tubuh sedemikian rupa agar dapat melakukan gerakan pukulan dengan efektif. Langkah kaki dalam permainan bulutangkis sering diistilahkan footwork.

Menurut Subardjah (2000), footwork adalah gerakan-gerakan langkah kaki yang mengatur badan untuk menempatkan posisi badan sedemikian rupa, sehingga memudahkan dalam melakukan gerakan memukul shuttlecock sesuai dengan posisinya. Sapta Kunta Purnama (2010) berpendapat bahwa: Prinsip dasar footwork dalam permainan bulutangkis adalah kaki yang sesuai dengan tangan yang digunakan untuk memegang raket saat memukul selalu berakhir sesuai arah tangan tersebut. Misalnya tangan memukul ke arah depan net, maka langkah akhir kaki yang sesuai tangannya juga didepan. Demikian pula saat memukul shuttlecock di daerah belakang, maka langkah akhir kaki yang sesuai tangannya juga dibelakang.

Footwork yang baik adalah seorang pemain dapat menjangkau berbagai sudut permainan sendiri ketika menerima bola dari lawan, baik di depan, samping, dan belakang permainan. Kemampuan footwork yang dimiliki seorang pemain dapat menghindarkan pemain dari kesalahan penempatan shuttlecock dan dapat menghemat tenaga dari kemampuan footwork yang dilakukakan.

Footwork yang tidak baik memiliki beberapa kerugian terhadap atlet, diantaranya adalah:

a. Atlet akan cepat kehilangan bola

b. Penempatan bola yang kurang baik

c. Pemborosan tenaga atau fisik atlet

\section{Kelincahan}

Kelincahan pada dasarnya adalah kemampuan seseorang atau atlet melakukan jenis gerakan tertentu dengan berubah arah secara tiba-tiba dan dilakukan secepat mungkin tanpa kehilangan keseimbangan pada saat melakukannya. Menurut Suharno (1992), Kelincahan adalah kemampuan dari seseorang untuk mengubah posisi dan arah secepat mungkin sesuai dengan situasi yang dihadapi dan dikehendaki. Jadi seseorang yang mampu mengubah satu posisi ke posisi lain yang berbeda dengan kecepatan tinggi dan koordinasi gerak yang baik berarti kelincahannya tinggi.

Oleh sebab itu pemain bulutangkis harus memiliki kelincahan yang sangat baik karena pola gerakan permainan dalam olahraga bulutangkis terjadi secara tiba-tiba dengan tempo yang sangat cepat, tiba bergerak ke depan, ke samping, dan ke belakang permainan sendiri ketika menerima bola dari permainan lawan.

\section{Daya Tahan}

Ismaryati (2006) mengatakan bahwa: daya tahan adalah kemampauan otot untuk melakukan suatu kerja secara terus menerus dalam waktu yang relative lama dengan beban tertentu. Sepintas dapat diamati bahwa pemain bulutangkis harus melakukan gerakan-gerakan seperti lari cepat, berhenti dengan tiba-tiba dan segera bergerak lagi. oleh karena itu dalam olahraga bulutangkis memerlukan daya tahan yang bagus, salah satunya daya tahan kardiorespirasi.

Menurut Suhendro (2004) menyatakan bahwa, daya tahan kardiorespirasi penting dalam bulutangkis untuk menentukan seberapa kuat pemain bertahan dalam bermain 
bulutangkis, daya tahan kardiorespirasi ini terutama dapat dicapai melalui peningkatan tenaga aerobik maksimal (VO2 maks) dan anaerobik.

Permainan bulutangkis merupakan olahraga yang cukup kompleks karena pemain harus memiliki komponen biomotor yang baik, seperti; daya tahan, kelincahan, kecepatan, kecepatan reaksi, power otot lengan dan tungkai, dan keseimbangan. Komponen daya tahan sebagai salah satu syarat jika seorang pemain ingin bertahan dalam 2 sampai dengan 3 set permainan yang bisa jadi permainan tersebut berlangsung selama 1 jam (satu) bahkan lebih. Sehingga komponen daya tahan merupakan kondisi fisik yang harus dimiliki oleh seorang pemain bulutangkis.

\section{METODE PENELITIAN}

\section{Variabel Penelitian}

Variabel dalam penelitian ini terdiri dari variabel bebas yaitu latihan footwork berbasis teknologi dan variabel terikat yaitu kelincahan dan daya tahan Siswa Putra bulutangkis PB. Lyansa.

\section{Jenis Dan Disain Penelitian}

Setiap jenis penelitian memiliki karakteristik yang berbeda, dan karena itu dalam penelitian akan diuraikan bentuk dan jenis penelitian. Jenis penelitian yang dilakukan ini termasuk dalam penelitian eksperimen dengan menggunakan rancangan penelitian seperti terlihat pada tabel 3.2. Menurut Maksum (2009) desain penelitian merupakan sebuah rancangan bagaimana suatu penelitian akan dilakukan. Rancangan tersebut digunakan untuk mendapatkan jawaban terhadap pertanyaan penelitian yang dirumuskan. Adapun desain penelitian yang digunakan adalah "one group pretest posttest design", seperti terlihat pada tabel 3.1 dibawah ini:

Table 3.1 rancangan penelitian

\begin{tabular}{c|c|c|}
\hline T1 & \multicolumn{1}{c|}{$\mathrm{X}$} & $\mathrm{T} 2$ \\
\hline Keterangan: & $\begin{array}{l}\text { T1 (Pretest) } \\
\text { tahan awal kelincahan dan daya } \\
\text { X (Perlakuan) }\end{array}$ \\
& footwork berbasis teknologi.
\end{tabular}

T2 (Posttest) : tes akhir kelincahan dan daya tahan

\section{Populasi dan Sampel Penelitian}

Populasi dalam penelitian ini adalah semua pemain yang berlatih di PB. Lyansa Masbagik utara yang berjumlah 14 orang yang masih duduk di bangku sekolah menengah atas (MA), dengan menggunakan tehnik purposive sampling untuk menentukan sampel dikarenakan subjek yang diteliti sudah diketahui karakteristiknya oleh peneliti.

\section{Instrument Penelitian}

Adapun instrument yang digunakan dalam penelitian ini adalah sebagai berikut:

\section{Kelincahan}

Tes rangkaian olah kaki ini diadakan untuk mengukur kelincahan gerakan kaki yang melangkah ke depan kanan-kiri, ke samping kanan-kiri, dan belakang kanan-kiri dalam permainan bulutangkis. Tes ini dikemukakan oleh Tohar (1992). Tes ini mempunyai validitas sebesar 0,98 dan reliabilitas sebesar 0,93.

\section{Daya Tahan}

Pengukuran daya tahan kardiorespirasi menggunakan tes multitahap (multistage fitness test) yaitu tes daya tahan yang bertujuan untuk mengetahui daya tahan paru jantung (VO2Max):

a. Membuat lapangan multi tahap dengan ukuran panjangnya lintasan tes multi tahap adalah jarak 20 meter.

b. Menyiapkan pemutar kaset dan juga kaset nya untuk suara dari tes multitahap (Bleep test) dan menyiapkan pencatatan hasil lari tes multitahap dengan pencatatan per level dan shuttle dari tes multitahap.

c. Berikan arahan kepada testi untuk mulai lari ke arah ujung atau akhir yang berlawan dari tempat start tes pertama dan sentukan kaki di belakang garis batas pada saat terdengar bunyi "tuut". Apabila testi sampai sebelum bunyi "tuut", testi harus bertumpu pada titik putar menunggu tanda bunyi berikutnya kemudian lari lagi ke arah garis yang 
berlawanan agar dapat mencapai tepat pada saat tanda berikutnya.

d. Pada akhir dari tiap menit interval waktu diantra dua bunyi "tuut" makin pendek, oleh karena itu kecepatan lari semakin bertambah cepat. Testi harus dapat sampai pada garis ujung pada waktu yang ditentukan dan tidak boleh terlambat, jika terlambat masuk garis ujung tiga kali berturut-turut maka akan dianggap berhenti dan di catat sesuai dari jumlah lari yang di dapat.

e. Semua testi harus laru lurus ke depan tidak boleh melakukan lari berkelokkelok atau melengkung karena akan memakan banyak waktu. Testi harus lari sebanyak-banyaknya untuk mengejar bunyi "tuut" sampai testi tidak bisa mengejar bunyi "tuut" pada kaset.

f. Hasil lari tes multitahap ini dicatat pada terakhir lari mendapat level dan shuttle berapa. Hasil tes ini kemudian di konsultasikan dengan tabel VO2Max (terlampir).

\section{Tehnik Pengumpulan Data dan Analisa Data}

Adapun tehnik yang digunakan dalam mengumpulkan data penelitian adalah dengan menggunakan metode dokumentasi untuk mendapatkan nama-nama subyek penelitian dan gambar-gambar terkait dengan obyek yang diteliti. Sedangkan metode tes perbuatan digunakan untuk memperoleh kemampuan awal kelincahan dan daya tahan atlet, dan tes akhir digunakan untuk mengetahui sejauhmana peningkatan kelincahan dan daya tahan setelah diberikan latihan footwork berbasis teknologi sinyal lampu dengan remote control.

Analisa data yang digunakan adalah uji-t paired sample test dengan uji prasyarat berupa uji normalitas dan uji homogenitas data dengan bantuan SPSS versi 17.0.

\section{HASIL DAN PEMBAHASAN \\ Deskripsi Data Kelincahan}

Menunjukkan terdapat perbedaan sebelum dan sesudah diberikan latihan footwork dengan teknologi dimana nilai mean sebelum perlakuan sebesar 14.7143 dan setelah perlakuan sebesar 18.2857. Sedangkan standar deviasi sebelum dan setelah latihan perbedaannya cukup kecil yaitu sebesar 2.67261 (postest) > 1.72888 (pretest). Skor kelincahan antara sebelum dikurangi sesudah latihan footwork dengan teknologi sebesar $3.57 \%$.

\section{Deskripsi Data Daya Tahan}

Deskripsi data Daya tahan menunjukkan mean sebelum diberikan perlakuan sebesar 6.6429, sedangkan setelah diberikan perlakuan sebesar 8.2857. yang artinya ada perbedaan rata-rata setelah diberikan perlakuan footwork dengan teknologi sinyal lampu dikurangi dengan sebelum diberikan latihan, atau dengan kata lain 8.2857-6.6429 $=1,64 \%$ tingkat peningkatan daya tahannya. Sedangkan standar deviasi 2.16997 sebelum diberikan perlakuan dan setelah diberikan latihan sebesar 2.23361

\section{Uji Prasyarat Hipotesis}

Sebelum dilakukan uji analisis statistic maka terlebih dahulu dilakukan uji persyarat untuk menentukan tehnik analisis yang tepat digunakan. Sependapat dengan Nisfiannoor (2009) menyatakan bahwa sebelum dilakukan uji $\mathrm{T}$ Test, dilakukan dulu uji normalitas untuk mengecek apakah data yang ada terdistribusi normal sebagai syarat untuk penggunaan teknik statistic parametric. Bila sebaran data tidak normal, teknik analisis diganti dengan Mann-Whitney. Data untuk kelincahan berdistribusi normal, atau dengan kata lain 0,600 dan $\mathrm{p}=0,865>0,05$ (data normal). Sedangkan sesudah pelatihan kolmogorov-smirnov $=0,694$ dan $p=0,722>$ 0,05 yang artinya data berdistribusi normal. Uji Homogenitas Kelincahan data yang diperoleh dengan mengacu pada levene test $=$ 1.771 dan $p=0,252>0,05$, maka varian data adalah sama (homogen).

\section{Uji Normalitas Daya Tahan}

data untuk kelincahan berdistribusi normal, atau dengan kata lain 0.876 dan $\mathrm{p}=$ $0,427>0,05$ (data normal). Sedangkan sesudah pelatihan kolmogorov-smirnov = 0,775 dan $p=0,585>0,05$ yang artinya data berdistribusi normal. Sedangkan uji homogenitas data dari analisis menggunakan levene test didapatkan hasil sebesar 1.012 dan 
$\mathrm{p}=0.065>0,05$, maka varian data sama (homogen). Sedangkan f hitung pada tabel 5.7 didapatkan angka sebesar 37.577 dan $\mathrm{p}=$ $0,000<0,05$. Dengan batas penolakan $\mathrm{H}_{0}$ : ditolak dan $\mathrm{H}_{\mathrm{a}}$ diterima. Jadi terdapat perbedaan yang signifikan antara sebelum dan sesudah diberikan perlakuan terhadap daya tahan pemain PB. Lyansa Masbagik.

\section{Uji Paired Samples Test Kelincahan}

Pada pengujian kedua ini dilihat dari hasil T-test yaitu pada sampel yang sama namun dengan perbedaan hasil pengaruh pada dua hal yang berbeda yaitu antara kelincahan dan daya tahan. Perbedaan tersebut bisa dilihat dari hail pengujian paire samples t-test pada tabel 5.9 pada tabel hasil kelincahan didapatkan hasil t-hitung $=8,095$ dan sig (p) $=0,000<0,05$, maka $\mathrm{H}_{0}$ ditolak dan $\mathrm{H}_{\mathrm{a}}$ diterima. Jadi ada perbedaan kelincahan antara sebelum dan sesudah perlakuan. Dengan kata lain, adanya perlakuan tersebut sangat membantu dalam meningkatkan kemampuan kelincahan atlet bulutangkis PB. Lyansa Masbagik.

\section{Uji Paired Samples Correlations Daya Tahan}

Paired korelasi pada tabel 5.8 menunjukkan angka sebesar 0,959 dengan nilai signifikan sebesar $(\mathrm{p})=0,000<0,05$ yang artinya terdapat korelasi antara sebelum dan sesuah perlakuan latihan footwork berbasis teknologi terhadap daya tahan dengan kategori hubungan sangat kuat dengan mengacu pada rumus $\mathrm{KP}=\mathrm{r}^{2} \times 100 \%$, maka diperoleh kontribusi sebesar latihan footwork berbasis teknologi sebesar $=91,97 \%$ dan $8,03 \%$ dipengatuhi oleh factor lain yang tidak bisa dikontrol oleh peneliti ketika pelaksanaan latihan berkahir.

\section{PEMBAHASAN}

Berdasarkan hasil analisa data bahwa kelincahan dipengaruhi cukup besar oleh latihan footwork dengan teknologi dibandingkan dengan peningkatan daya tahan. Kelincahan memiliki persentase peningkatan sebesar $3.57 \%$, sedangkan pada daya tahan sebesar $1.64 \%$. Sehingga dapat dikatakan terdapat peredaan antara sebelum dan sesudah diberikan latihan footwork berbasis teknologi terhadap pemain bulutangkis PB. Lyansa
Masbagik. Hal ini diperkuat dengan beberapa hasil penelitian dari Astrawan, Adiputra, Jawi (2016:18) dengan pola penelitian menggunakan perbandingan latihan footwork 10 repetisi dengan 2 set dan 5 repetisi dengan 4 set untuk meningkatkan kekuatan otot tungkai dan kelincahan. Namun dari hasil penelitian astrawan $\mathrm{dkk}$ peningkatkan kekuatan otot tungkai memiliki persentase yang lebih besar dibandingkan dengan kelincahan $25 \%$ untuk kekuatan otot tungkai dan $2 \%$ untuk peningkatkan kelincahan. Sedangkan menurut Nugraha (2015:86) dengan judul penelitian "Pengembangan sinyal lampu 3 warna untuk alat bantu kelincahan footwork pada klub PB. Mandiri Pati”. Produk pengembangan sinyal lampu 3 warna untuk alat bantu kelincahan footwork ini sudah dapat dipraktikkan kepada subjek uji coba produk berdasarkan hasil analisa dari evaluasi ahli prototype didapat rata-rata persentase $76,66 \%$, evaluasi kepelatihan I rata-rata $83,33 \%$, dan hasil kepelatihan II rata-rata $81,66 \%$. Hasil analisi data kelompok kecil rata-rata $71,21 \%$. Dan hasil analisis data uji coba kelompok besar rata-rata $82 \%$.

Sedangkan penelitian yang dilakukan oleh Nandika, et al. (2017) Berdasarkan hasil penelitian terdapat perbedaan antara hasil Pretest dan Posttest yang diperoleh dari hasil uji coba kelompok besar yang sebelumnya telah dilakukan Pretest dan Posttest yang dilakukan pada anak pemula (U-15). Sebelum model-model latihan strokes bulutangkis diterapakan, peneliti melakukan Pretest atau tes awal untuk mengetahui tingkat kemampuan dasar strokes bulutangkis yang dimiliki oleh subyek yang akan diteliti. Hasil Pretest yang diperoleh adalah 2852. Setelah itu treatment diberikan dengan menggunakan model-model latihan strokes bulutangkis yang telah dikembangkan. Setelah treatment diberikan maka subyek di tes kembali menggunakan tes yang sama dengan tes keterampilan strokes bulutangkis seperti sebelumnya. Tes ini dinamakan Posttest yang digunakan untuk mengetahui apakah terdapat peningkatan keterampilan strokes bulutangkis setelah pemberian treatment berupa modelmodel latihan strokes bulutangkis berbasis 
footwork untuk anak pemula (U-15), maka diperoleh angka sebesar 3314. Berdasarkan keterangan tersebut dapat dikatakan bahwa model latihan strokes bulutangkis berbasis footwork untuk anak pemula (U-15) yang dikembangkan efektif dan meningkatkan keterampilan strokes bulutangkis.

Produk yang dikembangkan ini bertujuan untuk membentuk dan meningkatkan tercapainya tujuan latihan strokes bulutangkis untuk anak pemula (U15). Setelah dikaji produk ini terdapat beberapa kelemahan yang perlu pembenahan, maka dapat disampaikan beberapa keunggulan produk ini antara lain: 1) Anak lebih aktif dalam mengikuti proses latihan yang aman, 2) Anak terlihat gembira dan antusias, 3) Model latihan dilakukan dari yang mudah ke yang sulit, 4) Bisa dilaksanakan ditempat dan waktu yang diinginkan. Sedangkan pendapat dari Riandinata et al. (2018:61) model latihan keterampilan footwork (RD) untuk atlet bulutangkis pemula usia 13-15 tahun berdasarkan pada bagian hasil data yang dibuat yang didapat dari uji kelompok kecil, uji kelompok besar dan uji efektifitas serta pembahasan hasil penelitian dapat disimpulkan bahwa: (1) Semua item model latihan dapat diterapkan, akan tetapi harus disesuai dari yang sistematis, dari yang mudah sampai ke yang sulit agar kemampuan footwork atlet meningkat, (2) Pada saat melakukan model footwork, atlet tidak kembali ke titik tengah, atlet terburu-buru ingin menyelesaikan tugasnya, maka tugas pelatih menginstruksikan kepada atlet untuk setiap melakukan footwork harus kembali ke tengah terlebih dahulu, kemudian baru kembali melakukan footwork sesuai dengan arahannya.

\section{KESIMPULAN}

Berdasarkan hasil analisa pada data penelitian tentang pengaruh latihan footwork berbasis teknologi terhadap kelincahan dan daya tahan pada pemain bulutangkis PB. Lyansa Masbagik, dapat disimpulkan:

1. Pada analisa data samples correlations antara sebelum dan sesudah perlakuan sebesar 0,801 dengan tingkat hubungan sangat kuat, yang artinya kontribusi latihan footwork berbasis teknologi terhadap kelincahan sebesar $64,16 \%$, sedangkan sisanya sekitar $34,84 \%$ dipengaruhi oleh factor lain. Sedangkan uji T-test didapatkan angka sebesar = 8,095 dan sig $(\mathrm{p})=0,000<0,05$ yang mengindikasikan bahwa terdapat perbedaan kelincahan antara sebelum dan sesudah perlakuan, dengan kata lain perlakuan berupa latihan footwork berbasis teknologi mampu meningkatkan kelincahan pemain bulutangkis pada PB. Lyansa Masbagik.

2. Uji paired samles korelasi didapatkan hasil r-hitung sebesar 0,959 dengan nilai $\mathrm{p}=0,000<0,05$ yang artinya terdapat korelasi yang sangat kuat antara sebelum dan sesudah perlakuan latihan footwork berbasisi teknologi terhadap daya tahan. Korelasi yang sangat kuat tersebut didapatkan melalui KP $=r^{2} \times 100 \%$, maka didapatkan hasil $91,97 \%$ dan $8,03 \%$ dipengaruhi oleh factor lain yang tidak bisa peneliti control setelah sesi latihan berakhir. Sedangkan hasil T-test menunjukkan angka sebesar $=9,706$ dan $\operatorname{sig}(\mathrm{p})=0,000<0,05$ yang mengindikasikan bahwa terdapat perbedaan daya tahan antara sebelum dan sesudah perlakuan latihan footwork berbasisi teknologi yang diberikan selama 45 hari (6 minggu).

3. Analisis korelasi maupun uji paired samples T-test hasil kelincahan (r-hitung $=0,801$ dan $\mathrm{T}$-test $=8,095$ ) lebih kecil pengaruhnya dibandingkan dengan daya tahan $(r=0,959$ dan $\mathrm{T}=9,706)$, atau dengan kata lain latihan footwork berbasis teknologi lebih berpengaruh terhadap daya tahan dari pada kelincahan atlet PB. Lyansa Masbagik tahun 2019.

\section{DAFTAR PUSTAKA}

\section{Herman, S., 2004. Pendekatan Keterampilan} Taktis Dalam Pembelajaran Bulutangkis. Jakarta: Direktorat Jenderal Olahraga, Depdiknas.

Kridiyana, R., 2010. Merangsang Gerak Reaksi Olahragawan Bulutangkis Dengan Menggunakan Bola Lampu. Sumber: https://ratihkrisdiyana.wordpress.com/ 2010/12/15/merangsang-gerak-reaksi- 
olahragawan-bulutangkis-denganmenggunakan-bola-lampu/. (Artikel, posted on Desember 15. 2010). Diakses tanggal 7 Maret 2019.

Maksum, A., 2009. Metodologi Penelitian Dalam Olahraga. Surabaya. Unesa University Press.

Muthiarani, A., 2017. Pengaruh Latihan Shadow Menggunakan Langkah Berurutan Dan Langkah Bersilangan Terhadap Kelincahan Footwork Atlet Bulutangkis PB. Wiratama Jaya Yogyakarta. Fakultas ilmu Keolahragaan: Universitas Negeri Yogyakarta.

Nugraha, F., 2015. Pengembangan Sinyal Lampu 3 Warna Untuk Alat Bantu Kelincahan Footwork Pada Klub Pb.Mandiri Pati Tahun 2015 (Skripsi). Semarang: Universitas Negeri Semarang.

Nugraha, Febby. 2015. Pengembangan Sinyal Lampu 3 Warna Untuk Alat Bantu Kelincahan Footwork Pada Klub PB. Mandiri Pati Tahun 2015. Fakultas Ilmu Keolahragaan: Universitas Negeri Semarang.

Nugraha, Febby. 2015. Pengembangan Sinyal Lampu 3 Warna Untuk Alat Bantu Kelincahan Footwork Pada Klub PB. Mandiri Pati Tahun 2015. Fakultas Ilmu Keolahragaan: Universitas Negeri Semarang.

Nurhasan, 2000. Tes Dan Pengukuran Pendidikan Olahraga. Jakarta: Fakultas Pendidikan Olahraga Dan Kesehatan. Universitas Pendidikan Indonesia.

Purnama, S. K., 2010. Kepelatihan Bulutangkis Modern. Surakarta: Yuma Pustaka.

Sujianto, E. A., 2009. Aplikasi Statistik Dengan SPSS 16.0. Jakarta: Prestasi Pustaka. 